\title{
Olgu Sunumu
}

\section{A Giant Pericardial Cyst as a Rare Cause of Shortness of Breath}

\author{
Umut KOCABAŞ*๑, Atilla PEKÇOLAKLAR** $\odot$
}

\section{ABSTRACT}

Pericardial cysts are uncommon benign congenital cardiac anomalies and they are usually asymptomatic. This case report demonstrates the importance of pericardial cysts and its rare complications such as cardiac compression and shortness of breath.

Keywords: pericardial cysts, cardiac compression, shortness of breath

\section{öZ}

Nefes Darlığının Ender Bir Nedeni Olarak Dev Perikardiyal Kist

Perikardiyal kistler ender görülen, iyi huylu, konjenital kardiyak anomalilerdendir ve siklıkla asemptomatik seyrederler. Bu olgu raporunda, perikardiyal kistlerin önemi ve ender bir komplikasyonu olarak kardiyak kompresyona bağlı gelişen nefes darlığ olgusu sunulmuştur.

Anahtar kelimeler: perikardiyal kist, kardiyak kompresyon, nefes darlı̆̆
A 51-year-old man presented to our outpatient clinic with symptoms of atypical chest pain and shortness of breath. His medical history, physical examination and electrocardiography findings were unremarkable. $\mathrm{Tr}-$ ansthoracic echocardiography revealed normal valvular functions, normal-sized cardiac chambers, and left ventricular ejection fraction was $67 \%$ as calculated based on modified Simpson's method. Two-dimensional transthoracic echocardiography subcostal view showed an echo-free space next to the right atrium at the right cardiophrenic angle (Figure 1). Continuous wave Doppler echocardiography demonstrated respiratory changes in right ventricular diastolic filling, increased respiratory variations in transtricuspid diastolic flow and dilated inferior vena cava due to severe right atrial compression by a giant pericardial cyst. Magnetic resonance imaging revealed an oval mass in the right cardiophrenic angle measuring $8.2 \times$ $5.1 \times 6.4 \mathrm{~cm}$ with low intensity on T1-weighted images and homogeneous high intensity on T2-weight- ed images without contrast enhancement consistent with pericardial cyst (Figures 2a-d). The patient was referred to cardiothoracic surgery. After general anaesthesia and a right-sided thoracotomy, the pericar-

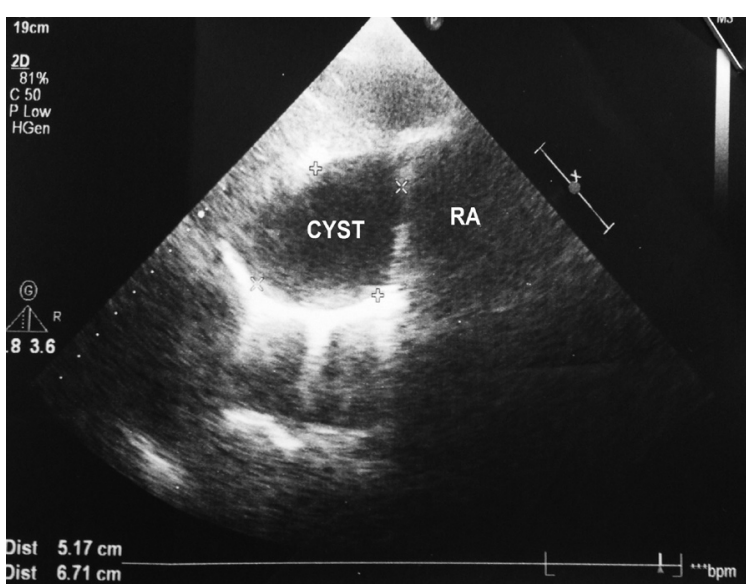

Figure 1. Two-dimensional transthoracic echocardiography image (subcostal view) showing an echo-free space next to the right atrium at the right cardiophrenic angle (RA: right atrium).

*Edremit Devlet Hastanesi, Kardiyoloji Kliniği

**Soma Devlet Hastanesi, Göğüs Cerrahisi Kliniği

Yazışma adresi: Uzm. Dr. Umut Kocabaş, Edremit Devlet Hastanesi, Kardiyoloji Kliniği, 10300 Balıkesir

e-mail: umutkocabas@hotmail.com 


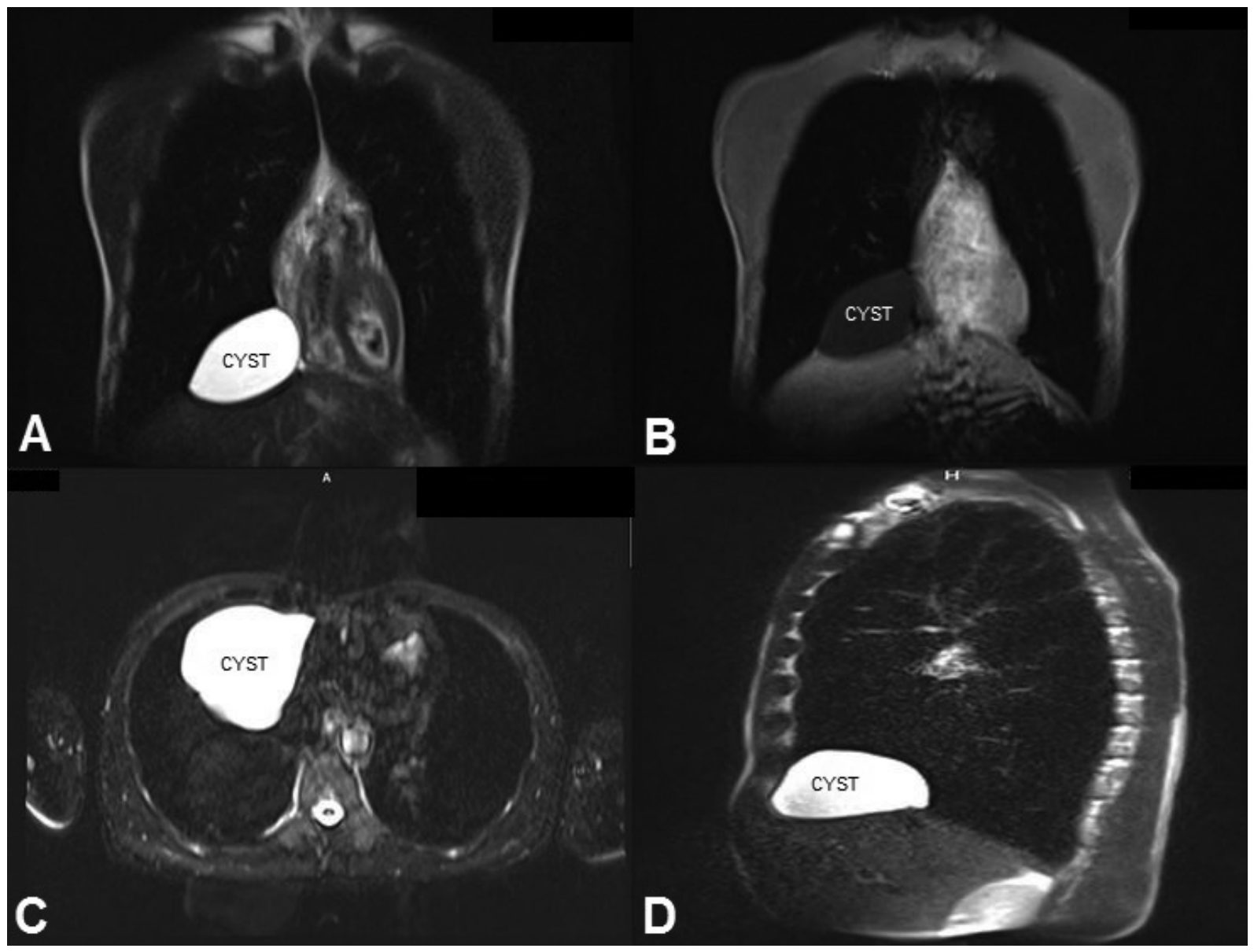

Figure 2. Magnetic resonance imaging demonstrating an oval mass in the right cardiophrenic angle with high intensity on coronal (a), axial (c), sagittal (d) T2-weighted images and low intensity on coronal (b) T1-weighted images and without contrast enhancement consistent with pericardial cyst.

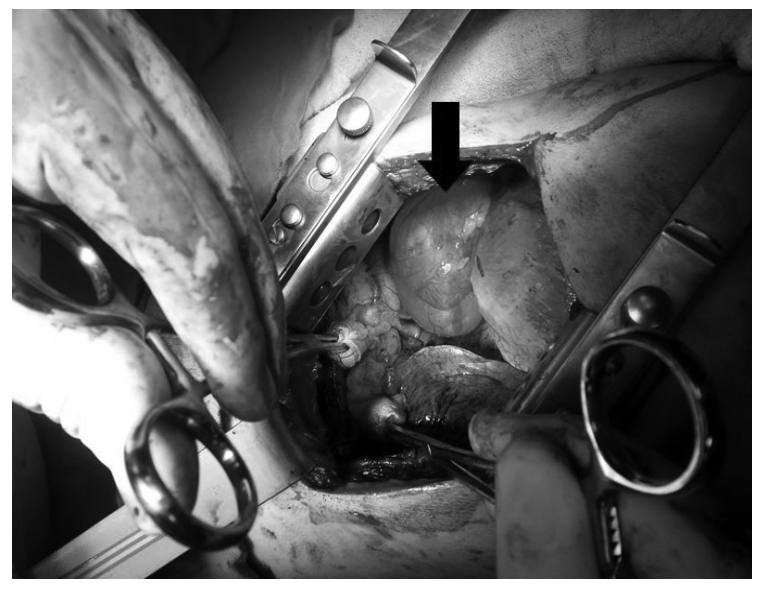

Figure 3. Intraoperative image demonstrating giant pericardial cyst (arrow).

dial cyst was seen on the right side of the pericardium measuring $10 \times 6 \times 8 \mathrm{~cm}$ (Figure 3). Needle aspiration revealed serous fluid and the pericardial cyst was totally excised without any complications. Intercostal nerve block was used for management of post-thoracotomy pain. Histopathologic evaluation of surgical specimen confirmed the diagnosis of a pericardial cyst. The patient was discharged from hospital 8 days after surgery. During his one month follow-up visit, he was totally asymptomatic and echocardiographic examination was normal.

Pericardial cysts are uncommon benign congenital anomalies with a prevalence of 1:100.000 ${ }^{[1]}$. Pericardial cysts are usually asymptomatic and detected incidentally during noninvasive imaging tests ${ }^{[2]}$. Pericardial cysts are generally located at the right cardiophrenic angle and rarely located in other mediastinal locations nearby the diaphragm ${ }^{[3]}$. Complications due to pericardial cysts are uncommon. Rarely, pericardial cysts may be associated with unexpected life-threatening events such as rupture, pericardial 
tamponade and sudden death ${ }^{[4,5]}$. Diagnostic modalities for pericardial cysts include transthoracic echocardiography, computed tomography and magnetic resonance imaging ${ }^{[6]}$. Intensive follow-up program is recommended for asymptomatic patients. Large sized, symptomatic and/or complicated cysts or those carrying suspicion of malignancy may be resected ${ }^{[7-9]}$. This case demonstrates the importance of pericardial cysts and its rare complications such as cardiac compression and shortness of breath.

\section{Conflict of interest: None.}

\section{Funding statement: None.}

\section{REFERENCES}

1. Hynes JK, Tajik AJ, Osborn MJ, Orszulak TA, Seward JB. Two-dimensional echocardiographic diagnosis of pericardial cyst. Mayo Clin Proc. 1983;58:60-3.

2. Duwe BV, Sterman DH, Musani AI. Tumors of the mediastinum. Chest. 2005;128:2893-909. https://doi.org/10.1378/chest.128.4.2893

3. Stoller JK, Shaw C, Matthay RA. Enlarging, atypically located pericardial cyst. Recent experience and literature review. Chest. 1986;89:402-6.

https://doi.org/10.1378/chest.89.3.402

4. Shiraishi I, Yamagishi M, Kawakita A, Yamamoto Y, Hamaoka K. Acute cardiac tamponade caused by massive hemorrhage from pericardial cyst. Circulation. 2000;101:E196-7. https://doi.org/10.1161/01.CIR.101.19.e196

5. Fredman CS, Parsons SR, Aquino TI, Hamilton WP. Sudden death after a stress test in a patient with a large pericardial cyst. Am Heart J. 1994;127:946-50. https://doi.org/10.1016/0002-8703(94)90572-X

6. Comoglio C, Sansone F, Delsedime L, Campanella A, Ceresa F, Rinaldi M. Mesothelial cyst of the pericardium, absent on earlier computed tomography. Tex Heart Inst J. 2010;37:354-7.

7. Najib MQ, Chaliki HP, Raizada A, Ganji JL, Panse PM, Click RL. Symptomatic pericardial cyst: a case series. Eur J Echocardiogr. 2011;12:E43. https://doi.org/10.1093/ejechocard/jer160

8. Islas F, de Agustin JA, Gomez de Diego JJ, Olmos C, Ferrera C, Luaces M, et al. Giant pericardial cyst compressing the heart. J Am Coll Cardiol. 2013;62:e19. https://doi.org/10.1016/j.jacc.2013.02.102

9. Hekmat M, Ghaderi H, Tatari H, Arjmand Shabestari A, Mirjafari SA. Giant pericardial cyst: A case report and review of literature. Iran J Radiol. 2016;13:e21921. https://doi.org/10.5812/iranjradiol.21921 